\title{
Effect of plant density and some safety compounds on growth and productivity of green snap bean
}

\author{
Abo-Sedera,F.A. ${ }^{1}$, Nadia S. Shafshak ${ }^{1}$,S.M.Eid ${ }^{1}$ A.H.Amer ${ }^{2}$ and S.A.El-Atabany ${ }^{2}$ \\ 1- Hort.Dept.,Fac. Agric.,Benha Univ.,ARE. \\ 2-Hort. Res. Inst., Agric. Res. Center, Giza, Egypt
}

\begin{abstract}
Two field experiments were conducted during the two successive seasons of 2010/2011 and 2011/2012 at the Experimental Farm, Kaha station, Kalubia Governorate to study the effect of using four plant densities $(5 \mathrm{~cm}, 7.5 \mathrm{~cm}$ apart on one side of the irrigation line, 10 and $15 \mathrm{~cm}$ apart on two sides of the irrigation line) and five safety materials, i.e. amino more, yeast extract, oligo-x and salicylic acid in addition to the control as foliar spray on snap bean plants and the effect of that on vegetative growth, green pods yield and physical as well as chemical pod characters of cv. Poulista. The results indicated that, plant density $7.5 \mathrm{~cm}$ on one side of ridge $\left(22 \mathrm{plant} / \mathrm{m}^{2}\right)$ and sprayed with yeast extract, amino more or oligo-x, respectively, gave the highest values of all measured vegetative growth parameters (plant length, number of branches and leaves/plant, fresh and dry weight of plant), pod number/plant and pod yield/plant except plant length and stem diameter in both growing seasons. Moreover, planting at $5 \mathrm{~cm}$ on one side of ridge $\left(33 \mathrm{plant} / \mathrm{m}^{2}\right.$ ) and sprayed with yeast extract in the first season and amino more in the second one were the best treatments for pod yield/fed. It is obvious that plant density $15 \mathrm{~cm}$ on two sides of ridge and spraying plants with yeast extract, amino more or oligo-x, respectively increased the values of all chemical properties but didn't reach to $5 \%$ level of significance except N\%, protein $\%$ in the second season.

Generally, it can be recommend by using plant density $5 \mathrm{~cm}$ on one side $\left(33\right.$ plant/ $\left.\mathrm{m}^{2}\right)$ or $7.5 \mathrm{~cm}$ on one side $\left(22 \mathrm{plant} / \mathrm{m}^{2}\right)$ and foliar spray by yeast extract, amino more followed by oligo-x to obtain the highest green pod yield with best quality.
\end{abstract}

Keywords: snap bean, plant density, yeast, amino acids, seaweed and salicylic acid

\section{Introduction}

Bean is considered as one of the most important and economic vegetable crops in Egypt. It does not require large amounts of fertilizers, plus it is considered as a short season crop, where it produce green pod yield through short period after two months from sowing. More over, it is one of the crops that cause soil fertility neither consumes nor depletes soil nutrients. It's also one of the few vegetable crops that can be grown for either local consumption or exportation. Moreover, the green pods as well as dry bean seeds contain cheap source from protein and carbohydrate. The total area devoted to green beans during winter season of 2011 was 57873 fed., this area produced 251279 ton as an average yield of 4.079 ton/fed. according to the Statistics of Ministry of Agriculture 2013.

Plant density is a prime factor in vertically increasing the yield (Mohamed 2008 on faba bean; Abd El-Latif 2009 on cowpea; Kazemi et al., 2012 on snap bean) where, the highest plant density increased yield. There are many reports showing the importance of plant density on vegetative trails of other leguminous crops. Such reports indicated increasing plant height with increasing plant density. Where as, number of branches and leaves per plant as well as leaf area per plant were decreased with increasing plant density( Abobaker, 2008 on snap bean ; Abd El-Latif et al.,2009 on cowpea ;Moniruzzaman et al.,2009 on French bean; El Naim and Jabereldar, 2010 on cowpea ; Darwesh, 2012 on cowpea) .

In recent years the world focused his attention to minimize environmental pollution and human health impacts, by reducing the use of synthetic fertilizer and chemicals in crops production, especially by fresh eaten vegetables (IFAOM/SOEL, 2000 and FAO/TTC, 2001). Several investigators using some nutritional safety compounds as a foliar spray, soil application and foliar spray combined with soil application to enhance its growth and maximizing the yield be using some natural extracts which are non toxic, environmentally friendly, of organic sources and costless.

Concerning yeast which contents protective agents, i.e., sugars, proteins, amino acids and several vitamins (Shady, 1978). His treatments suggested participating a beneficial role regarding growth and yield due to its cytokinens content (Barnett $\boldsymbol{e t}$ al., 1990). In this respect, it was found that yeast improves the formation of flower initiation due to its effect on 
carbohydrates accumulation (Winkler et al., 1962). Also, reports were mentioned about its stimulatory effects on cell division and enlargement, as well as protein nucleic acid and chlorophyll formation (Fathy and Farid, 1996).Improving growth and fruiting yield and overall quality of horticultural plants by yeast application was reported by (Tartoura (2001)who mentioned that spraying pea plants with yeast extract three times induced significant increase in all growth characters, i.e. plant height, number of leaves as well as fresh and dry weight of shoots/plant compared with the untreated control plants. In addition, Amer (2004) found that spraying common bean (Phasealus vulgaris $L$.) with yeast at the highest rate $(2 \mathrm{~g} / \mathrm{l}$.) gave higher values of all growth parameters, i.e. plant height, number of leaves/plant, leaf area and dry weigh/plant comparing with the control, In this regard, it is known that increment of leaf characteristics (number and area) could be a basic for increasing photosynthetic efficiency. These results are in agreement with those mentioned by El-Tohamy and El-Greadly, (2007), El-Desouky et al. (2011), Abou El -Yazied and Mady,(2012) and Gaafar(2014) for yeast.

Regarding to seaweed extract, several investigators showed that the great importance of this compounds due to it contain high levels of organic matter, micro elements ( $\mathrm{Fe}, \mathrm{Cu}, \mathrm{Zn}$, Co, Mo, Mn , and Ni), vitamins and amino acids and also, rich in growth regulators such as auxins , cytokinens and gibberellins (Blunden,1991,Crouch and Van Staden, 1994 and Khan et al.,2009).The beneficial effect of seaweed extract is a result of many components that work synergistically at different concentrations (Fornes $\boldsymbol{e t}$ al.,2002).In this respect, all the crude extracts of seaweed increased protein content in shoot systems, total soluble sugars and chlorophyll content in faba bean leaves. (El-Sheekh and Saied, 1999). Exogenous application of seaweed extract has already been shown to enhance plant growth, yield and its quality as reported by Nour and Eisa (2009) on snap bean, Abdel-Aziz and Gaafer (2012) on tomato, who found that spraying tomato plants with Elgeferet (as a rich source of seaweed extract) at dose of $4 \mathrm{~cm} / 1$ four times induced superior improvement on growth, fruit yield and its quality comparing with the control or the other used compounds. Abou El-Yazied et al. (2012) on snap bean, Kumar et al. (2012) on green gram and Gaafar (2014) on snap bean came to similar results.

Regarding to amino more which contains mixture of amino acids, it is known that, amino acids as organic nitrogenous compounds stimulated cell growth acting as buffers maintaining favorable $\mathrm{pH}$ value within the plant cell as well as synthesizing other organic compounds such as protein, amines, purines, pyrimidines, alkaloids, vitamins, enzymes, terpenoids and others (Goss, 1973). So the importance of amino acids on enhancing plant growth and its productivity it had a positive effects on plant growth, yield and overall quality of crops, i.e. amino acids are fundamental ingredients in the process of protein synthesis, formation of vegetable tissue and chlorophyll synthesis. Similar effects and findings about amino acids were indicated by Nour and Eisa (2009), Abd el- Mawgoud et al. (2011), El-Awadi et al. (2011) and Gaafar (2014) on snap bean. Moreover, amino acids are precursors or activators of phytohormones and growth substance (i.e. alternative routes of IAA synthesis exist in plants) all starting from tryptophan (amino acid) (Marschner 1995). The biosynthesis of cinamic acids (which are the starting materials for the synthesis of phenols) are derived from phenylalanine and tyrosine (tyrosinea is hydroxy phenyl amino acid that used to build neurotransmitters and hormones). Function of amino acid were found also in the synthesis of other organic compounds, amines, Purines and pyrimidines, alkaloids, vitamins enzymes, terpeniods and others as reported by (Pratelli and Pilot, 2007).Amino acids are important for pollination and fruit formation (Stitt et al. 2002).

Regarding to salicylic acid, it has been identified as one of the important phenolic compound in plants and is also reported as allelopathic chemical (Einhelling 1986), and is considered as a stress signaling compound in plant. Several studies indicated that foliar spray with salicylic acid increased the fresh and dry weights of plant, pod setting and total proteins of leaves and fruits (Liu Xenia et al.2000 and Sanaa $\boldsymbol{e t}$ al.2001 on broad bean). Kamal et al .2008, on pea found that yield and its components were increased, especially at the higher concentrations of salicylic acid (200 ppm).

\section{Materials and methods}

The present work was carried out during two successive seasons of 2011/2012 and 2012/2013 at the Experimental Farm, Kaha Station, Qalubia Governorate. Soil was clay in texture with 7.2 Ph, 3.5 EC $1.15 \%$ organic matters, 110 ppm N, 49 ppm P and $103 \mathrm{ppm} \mathrm{K}$. Seeds of snap bean cv. Poulista were obtained from Horticultural Research Institute, Agriculture Research Center, Egypt and sown on September $22^{\text {th }}$ in 2011 and 2012,. A split plot design system with three replicates was adopted where plant density was distributed in the main plots and growth compounds in the sub - plots. The area of each experimental plot was $30 \mathrm{~m}^{2}$ and consisted of one row (5 dripper lines with $10 \mathrm{~m}$ length each at $60 \mathrm{~cm}$ distance between dripper lines). The experiment included 20 treatments as follows:

\section{a- Plant densities}


1- 33 plants $/ \mathrm{m}^{2}$, one plant / hill at $5 \mathrm{~cm}$ apart on one side of the irrigation line.

2- 33 plants $/ \mathrm{m}^{2}$, one plant / hill at $10 \mathrm{~cm}$ apart on the two sides of the irrigation line.

3- 22 plants $/ \mathrm{m}^{2}$, one plant / hill at $7.5 \mathrm{~cm}$ apart on one side of the irrigation line.

4- 22 plants $/ \mathrm{m}^{2}$, one plant / hill at $15 \mathrm{~cm}$ apart on the two sides of the irrigation line.

\section{b- Foliar spraying treatments}

1 - Yeast extract at $200 \mathrm{ml} / \mathrm{l}$.
2-Oligo-x (sea weed extract) at $0.5 \mathrm{ml} / 1$.

3-Amino more at $0.75 \mathrm{ml} / 1$.

4-Salicylic acid at $50 \mathrm{ppm}$.

5- Distilled water (control).

The compounds used were applied three times within 15 days intervals, starting 21 days after sowing. Other agricultural practices required for snap bean production were carried out as commonly followed in the district. The compounds used in this study, i.e., composition and concentration are shown in following Table (1).

Table 1. Names and components of the materials used in this study

\begin{tabular}{|c|c|c|}
\hline $\begin{array}{l}\text { Compounds } \\
\text { name }\end{array}$ & Composition & Concentration \\
\hline 1-Control & Distilled water & - \\
\hline 2- Oligo-x & $\begin{array}{l}\text { Oligo skrdase } 0.3 \% \text {, Manito } 0.001 \% \text {, Cytokinins } 0.001 \% \text {, IAA } 0.002 \% \text {, } \\
\text { macro and micro elements }\end{array}$ & $0.5 \mathrm{~cm} / 1$ \\
\hline 3- Amino more & $15.13 \%$ amino acids ,macro and micro elements & $0.75 \mathrm{~cm} / 1$ \\
\hline 4- Salicylic acid & $\begin{array}{l}\text { A monohydroxy benzoic acid } \quad \mathrm{C}_{7} \mathrm{H}_{6} \mathrm{O}_{3} \\
\text { protein }(53 \%) \text { total carbohydrates }(47 \%) \mathrm{N}(12 \%) \mathrm{P}(0.13 \%) \mathrm{K}(03 .\end{array}$ & $50 \mathrm{ppm}$. \\
\hline 5- Yeast & $\begin{array}{l}\%), \mathrm{Mg}(0.013 \%), \mathrm{Ca}(0.02 \%), \mathrm{Na}(0.01 \%) \text {; micro-elements (ppm), Fe } \\
(0.13) \mathrm{Mn}(0.07), \mathrm{Zn}(0.04), \mathrm{Cu}(0.04), 3(0.016), \mathrm{Mo}(0.0003), \text { IAA }(0.5 \\
\mathrm{mg} / \mathrm{ml}) \text { and GA }(0.3 \mathrm{mg} / \mathrm{ml}) \text {. }\end{array}$ & $200 \mathrm{ml} / 1$ \\
\hline
\end{tabular}

Table 2. Monthly air temperature and relative humidity in Kalubia region during two seasons of the experiment.

\begin{tabular}{|c|c|c|c|c|c|c|c|c|}
\hline \multirow{3}{*}{ Month } & \multicolumn{4}{|c|}{$2010 / 2011$} & \multicolumn{4}{|c|}{$2011 / 2012$} \\
\hline & \multicolumn{3}{|c|}{$\begin{array}{c}\text { Tmperature } \\
{ }^{0} \mathrm{C}\end{array}$} & \multirow{2}{*}{$\begin{array}{c}\text { Relative } \\
\text { Humidity \% }\end{array}$} & \multicolumn{3}{|c|}{$\begin{array}{c}\text { Tmperature } \\
{ }^{0} \mathrm{C}\end{array}$} & \multirow{2}{*}{$\begin{array}{c}\text { Relative } \\
\text { Humidity \% }\end{array}$} \\
\hline & Max. & Min. & Average & & Max. & Min. & Average & \\
\hline September & 31.69 & 16.27 & 24.13 & 72 & 36.21 & 14.74 & 25.15 & 74 \\
\hline October & 38.07 & 10.83 & 21.30 & 71 & 33.94 & 13.05 & 23.20 & 73 \\
\hline November & 24.98 & 5.78 & 15.48 & 80 & 29.88 & 6.86 & 18.75 & 75 \\
\hline December & 21.79 & 2.50 & 12.45 & 84 & 27.27 & 3.77 & 13.83 & 83 \\
\hline January & 21.93 & 1.48 & 11.37 & 75 & 24.81 & 0.74 & 12.00 & 74 \\
\hline February & 20.74 & 3.37 & 11.25 & 69 & 26.26 & 1.74 & 13.33 & 77 \\
\hline
\end{tabular}

Data recorded:

Five plants from each plot were randomly taken after 50 days from seed sowing and the following data were recorded.

\section{1) Vegetative growth parameters :}

-Plant height $(\mathrm{cm}) \quad$-Stem diameter $(\mathrm{cm})$

Number of branches/plant

- Number of leaves/plant -Total fresh and dry weight of plant -Leaf area

The leaf area was calculated according to the following formula of Wallace and Munger (1965):
Leaf area $\left(\mathrm{cm}^{2}\right)=\frac{\text { Leaves dry weight }(\mathrm{gm}) \mathrm{xdisk} \text { area }\left(\mathrm{cm}^{2}\right)}{\text { Disk dry weight }(\mathrm{gm})}$

2) Green pods yield and its components:-

At harvest, green pods were continuously harvested at suitable maturity stage and in second pickings a random sample of 10 fresh green pods from each plot were taken randomly to determine the following data:

- Pod length -Pod diameter - Number and weight of pods/plant.

- Fresh and dry green pod weight - Total yield of green pods as ton/fed. 


\section{3) Chemical components:}

Pods of snap bean were dried in an electric forced-air oven at $70 \mathrm{c}^{\circ}$ to constant weight then fractionated and sifting. The fine powder (at $0.2 \mathrm{~g}$ ) of dry sample was digested in a mixture of sulphuric and perchloric acids according to Piper (1947). Total protein in pods was calculated by multiplying nitrogen in 6.25 as described by Stewart (1989). N (\%) using microkjeldahl, P (\%) using calorimetrically and $\mathrm{K}(\%)$ by flame photometer according to the methods described by Bremner and Mulvaney (1982), Olsen and Sommers (1982) and Jackson (1970) for N, P and $\mathrm{K}$, respectively.

\section{Statistical analysis:}

All data were subjected to statistical analysis according to the procedures reported by Snedecor and Cochran (1982) using M. stat program and means were compared by L.S.D multiple range tests at the 5 $\%$ level of probability in the two seasons of experimentation.

\section{Results and Discussion}

\section{I- Vegetative growth:}

\section{I.1 Effect of plant density}

The data reveal that plant density at $5 \mathrm{~cm}$ on one side of ridge (33plant/ $\mathrm{m}^{2}$ ) increased plant length compared with $10 \mathrm{~cm}$ on two sides of ridge (33plant $\left./ \mathrm{m}^{2}\right)$ in Table(3). On the other hand, plant density at $7.5 \mathrm{~cm}$ on one side of ridge $\left(22 \mathrm{plant} / \mathrm{m}^{2}\right)$ showed obvious increment in all other vegetative growth parameters in both growing seasons. There are many reports showing the importance of plant density on vegetative trails of other leguminous crops. Such reports indicated an increase in plant height with increasing plant density. Whereas, number of branches per plant, leaf area and number of leaves per plant were decreased with increasing plant density( Abubaker 2008 on snap bean, Abd El-Latif et al.2009 on cowpea ,Moniruzzaman et al.2009 on french bean, El Naim and Jabereldar 2010 on cowpea and Darwesh 2012)on cowpea.

\section{I.2 Effect of safety materials:}

As shown in Table 3, snap bean plants sprayed with yeast extract, amino more or oligo-x, respectively gave the highest values of vegetative growth parameters, i.e., plant length, number of leaves/plant, leaf area number of branches, stem diameter as well as the fresh and dry weight/plant as compared with either salicylic acid or water .In this regard, salicylic acid showed superiority in case of stem diameter comparing with all other used compounds. This was true in both growing season. These results may be due to a beneficial role during growth due to its cytokinens content (Barnett et al.1990), also, it was reported about its stimulatory effects on cell division and enlargement (Fathy and Farid, 1996). These results are also in agreement with those mentioned by ElTohamy and El-Greadly (2007), El-Desouky et al. (2011), Abou El-Yazied and Mady (2012) and Gaafar (2014) for yeast. Regarding to amino more which contain amino acids, it is known that, amino acids as organic nitrogenous compounds stimulated cell growth acting as buffers maintaining favorable $\mathrm{pH}$ value within the plant cell as well as synthesizing other organic compounds, such as protein, amines, purines, pyrimidines, alkaloids, vitamins, enzymes, terpenoids and others (Goss, 1973). These results are in agreement with those mentioned by Fawzy et al. (2010) on snap bean, Mawgoud et al. (2011) on green bean, El-Awadi et al. (2011) and Gaafar (2014) on snap bean. Further more olego-x contains high levels of organic matter, micro elements $(\mathrm{Fe}, \mathrm{Cu}, \mathrm{Zn}, \mathrm{Co}, \mathrm{Mo}, \mathrm{Mn}$, and $\mathrm{Ni}$ ), vitamins and amino acids and also, rich in growth regulators such as auxins, cytokinens and gibberellins (Blunden1991,Crouch and Van Staden, 1994 and Khan et al.,2009). The beneficial effect of seaweed extract is a result of many components that work synergistically at different concentrations (Fornes et al.2002), which can be found by Hanafy et al.(2010) on snap bean, Kavipriya et al.(2011) on green gram, Abou El -Yazied et al.(2012) and Gaafar (2014) on snap bean.

\section{I.3 Effect of the interaction:}

The results of the interaction effect between plant density and safety materials on vegetative growth, i.e., plant length, number of leaves, leaf area, number of branches/plan, stem diameter as well as fresh and dry weight of snap bean plant are shown in Table 3. It is obvious that plant density $7.5 \mathrm{~cm}$ on one side of ridge (22plant $\left./ \mathrm{m}^{2}\right)$ and sprayed with yeast extract gave the highest values of all vegetative growth parameters except plant length and stem diameter.

\section{2- Yield and yield components: \\ 2.1 Effect of plant density:}

Yield and yield attributes of snap bean show some significant results by using different plant density as shown in Table 4. The data show that the plants grown at plant density $5 \mathrm{~cm}$ on one side of ridge (33plant/ $\mathrm{m}^{2}$ ) increased pod yield ton/fed. On the other hand, plant density $7.5 \mathrm{~cm}$ on one side of ridge $\left(22 \mathrm{plant} / \mathrm{m}^{2}\right)$ gave the highest values of pod yield/plant, number of pod in both growing season and pod fresh weight in the first season. Moreover, pod length and pod diameter were significantly increased in the first season at plant 
density $10 \mathrm{~cm}$ on two sides of ridge $\left(33 \mathrm{plant} / \mathrm{m}^{2}\right)$ but the increase failed to reach the significant in the second season. Data also show that, there is no significant effect from using all plant density on pod dry weight in both growing seasons. This may be due to the higher number of plants per unit area, which can be found by Mohamed (2008) on faba bean, Abd El-Latif et al. (2009), El Naim and Jabereldar (2010) on cow pea and Kazemi et al. (2012) on snap bean.

\subsection{Effect of safety materials:}

Yield and yield attributes of snap bean show significant results by using different safety materials as shown in Table 4. The data show that the plants sprayed with yeast extract, amino more or oligo-x exerted the highest values of pod yield /plant, pod yield t/fed. number of pod and pod diameter in both growing seasons but the differences did not reach the $5 \%$ level of significance in the second season for pod length. There is no significant effect from using all safety materials on pod dry weight in both growing seasons. These results may be due to also that, yeast extract contain growth promoters and a relatively larger proportion of free amino acids and short peptides of two or three amino acids long than protein hydrolisates (Bevilcqua et al. 2008). Yeast is considered as a natural source of cytokines that stimulates cell division and enlargement (Kraig and Habe, 1980). These results also agree with those reported by Nour and Eisa (2009) on snap bean cv. Paulista, Abdel- Aziz and Zakhar (2010) on pea plant cv. Master B, Abou El-Yazied and Mady (2012) on broad bean cv. Super Aquadulse and Gaafar (2014) on snap bean cv. Pulista for yeast. Regarding to amino more which contain amino acids, it is known that, amino acids as organic nitrogenous compounds stimulated cell growth acting as buffers maintaining favorable $\mathrm{pH}$ value within the plant cell as well as synthesizing other organic compounds such as protein, amines, purines, pyrimidines, alkaloids, vitamins, enzymes, terpenoids and others (Goss, 1973). These results are in agreement with those mentioned by Nour and Eisa (2009) on snap bean cv. Paulista, Abdel- Aziz and Zakhar (2010) on pea, Fawzy et al. (2010), El-Awadi et al. (2011) on snap bean, Abd el-Mawgoud et al. (2011) on green bean and Gaafar (2014) on snap bean cv. Pulista . Concerning to olego-x contains which high levels of organic matter, micro elements $(\mathrm{Fe}, \mathrm{Cu}, \mathrm{Zn}$, Co, Mo, Mn , and Ni), vitamins and amino acids and also, rich in growth regulators such as auxins, cytokine and gibberellins was mentioned by (Blunden1991,Crouch and Van Staden 1994 and Khan et al.2009), Nour and Eisa (2009) on snap bean cv. Paulista, Abdel- Aziz and Zakhar (2010) on pea cv. Master B., Zodape $\boldsymbol{e t}$ al. (2010) on green gram and Gaafar (2014) on snap bean cv. Pulista .

\subsection{Effect of the interaction:}

The results in Table 4 revealed that the highest values of pod number/plant, pod yield/plant were obtained from plants sprayed with yeast extract followed by amino more at plant density $7.5 \mathrm{~cm}$ on one side of ridge $\left(22 \mathrm{plant} / \mathrm{m}^{2}\right)$. Moreover, plants sprayed with yeast extract at plant density $5 \mathrm{~cm}$ on one side of ridge (33plant/ $\mathrm{m}^{2}$ ) in the first and amino more in the second season were the best treatments for pod yield/fed. Meanwhile, the data show that there is no significant effect from using all plant density and safety compounds on pod length, pod diameter as well as fresh and dry pod weight in both seasons.

\section{3- Chemical properties:}

3.1 Effect of plant density:

Data in Table 5 show the effect of plant density on chemical properties of snap bean pods, i.e., N\%, P\% and $\mathrm{K} \%$ and protein percentage. It was found that the plant density $15 \mathrm{~cm}$ on two sides of ridge gave the highest value of all chemical properties except $\mathrm{K} \%$ in both seasons which was increased by the plant density $7.5 \mathrm{~cm}$ on one side of ridge. Obtained results are in agreement with those found by Arisha and Bardisi (1999) on common bean and Abubaker (2008) on snap bean.

\subsection{Effect of safety compounds:}

As shown in Table 5 spraying snap bean plants with safety compounds increased all chemical properties of snap bean pods, i.e., $\mathrm{N} \%, \mathrm{P} \%$ and $\mathrm{K} \%$ and protein percentage compared with the control. Yeast extract and amino acids increased mostly all chemical properties of snap bean pods. Regarding to yeast the results are in agreement with those mentioned by Nour and Eisa (2009), Ali (2010), Abou El Yazied and Mady (2012) and Gaafar(2014)on bean .

Concerning to the effect of amino more, it was found that, the plants sprayed with amino-more compound gave pods contain high concentration of $\mathrm{K}$, these result may be due to chemical structure of amino more, which contain mixture of amino acids, it is known that, Amino acids as organic nitrogenous compounds stimulated cell growth. (Goss, 1973).

The increases of chemical constituents by spraying yeast, amino more, olego- $\mathrm{x}$ and salicylic acid might be attributed to that macro and micronutrients increases the capacity of plant to absorb nutrients by the increase of root surface per unit of soil volume, as well as the high capacity

Of the plants supplied with macro and micronutrients in building up plant metabolites, which in turn contributes much to the increase of nutrients uptake (Mandour et al. 1986). 
Table 3. Effect of plant density and safety compounds foliar spray and their interaction on vegetative growth parameters of snap bean plants during 2011 and 2012 seasons.

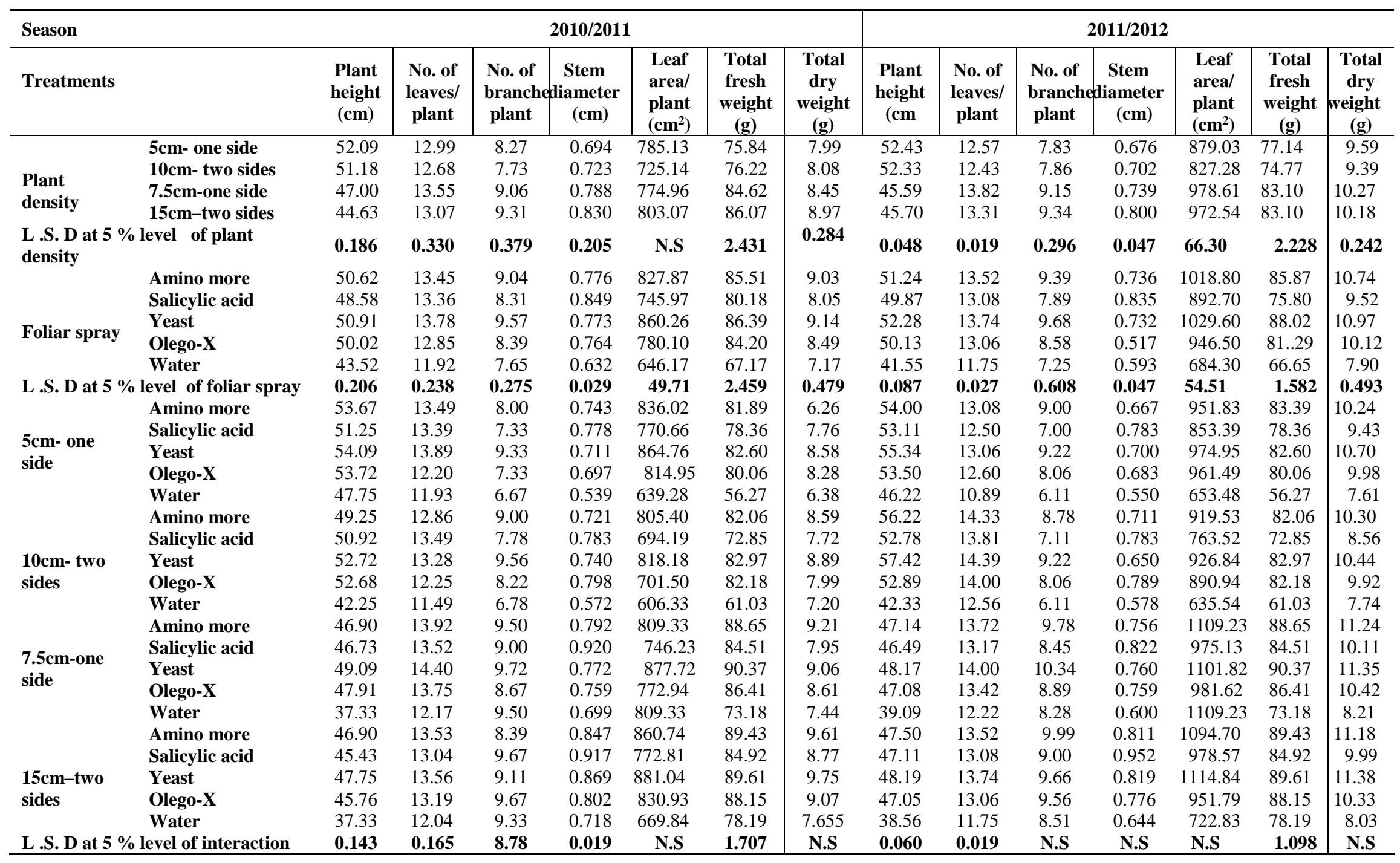


Table 4. Effect of plant density and safety compounds foliar spray and their interaction on yield and its components of snap bean plants during 2011 and 2012 seasons.

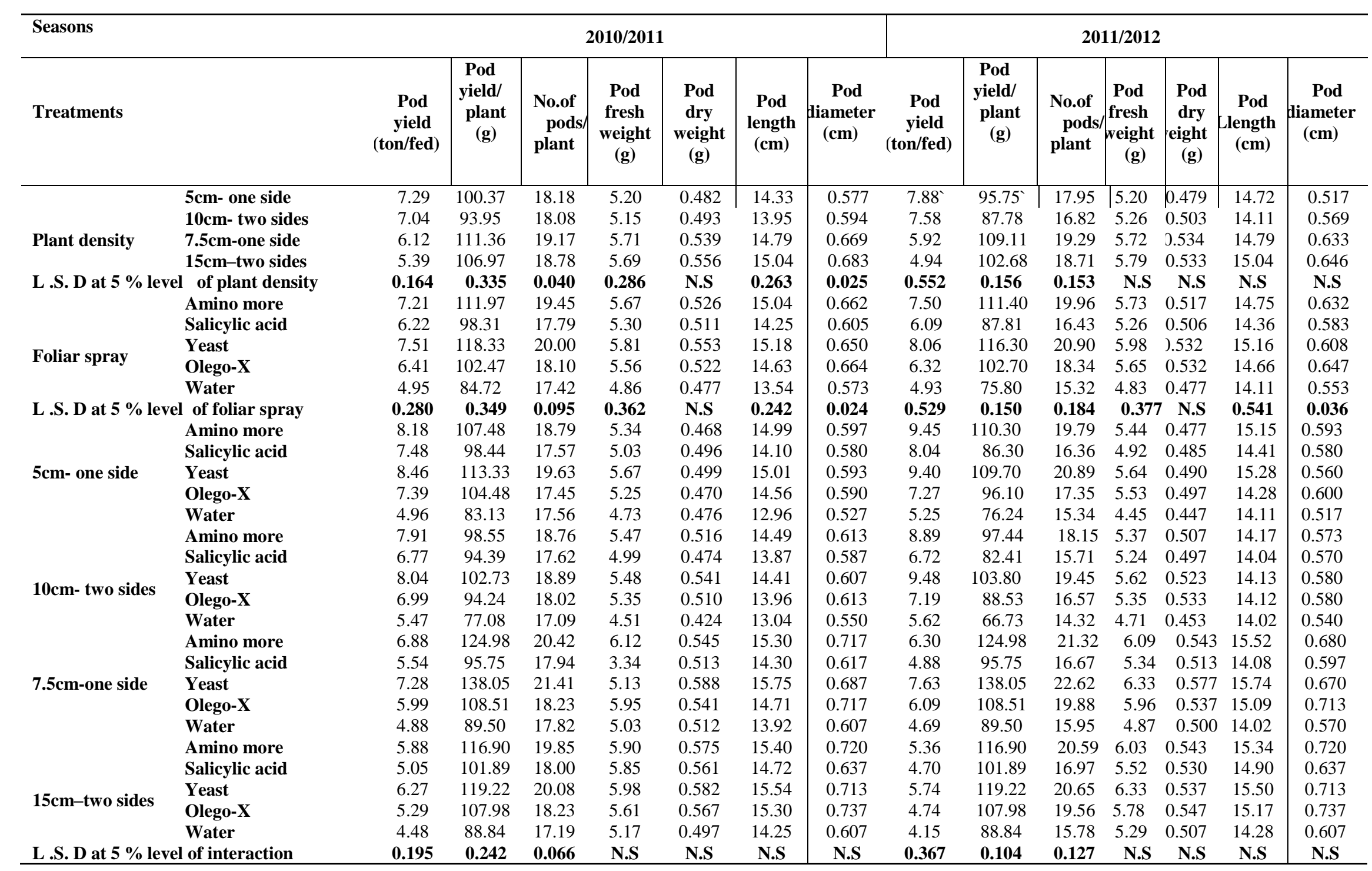


Table 5. Effect of plant density and safety compounds foliar spray and their interaction on the percentages of some chemical composition of snap bean pods during 2011 and 2012 seasons.

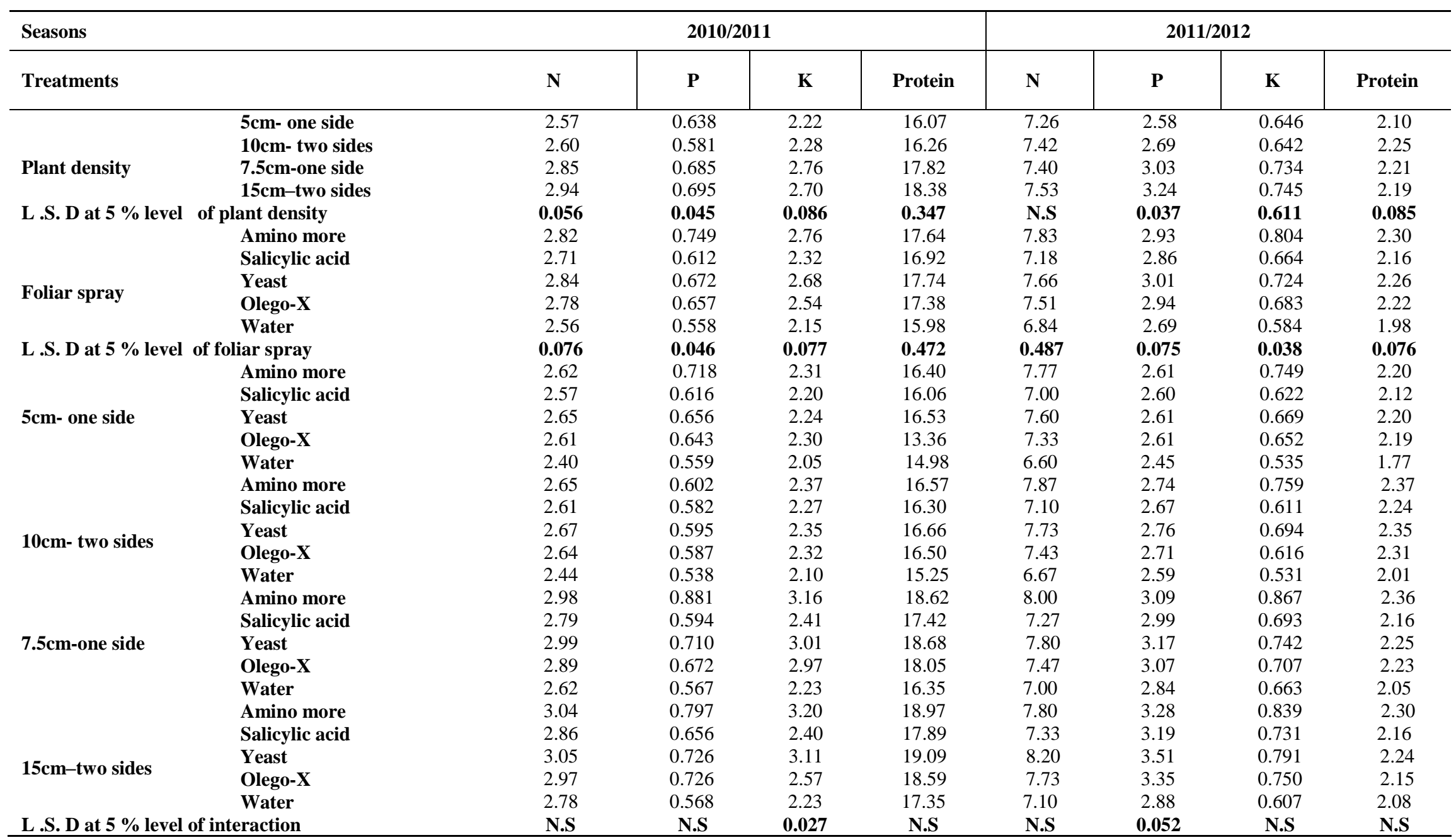




\subsection{Effect of the interaction:}

Effect of the interaction between plant density and safety materials on chemical properties, total protein, $\mathrm{N}, \mathrm{P}$ and $\mathrm{K} \%$ in snap bean pod are shown in Table 5. It is obvious that plant density at $15 \mathrm{~cm}$ on two sides of ridge and spraying plants with yeast, amino more or oligo-x, respectively increased the values of all chemical properties but didn't reach to $5 \%$ level of significance except $\mathrm{N} \%$, protein $\%$ in the second season

\section{References}

Abd El-Latif,A.A.,S.H.Hedawy and M.S.Barsom (2009). Effect of planting date and plant densities on cowpea productivity growing at new Valley . J . Agric. Sci., Mansoura 34(12):11247-11258.

Abdel- Mawgoud,A.M.R.,A.M. R.ElBassiouny,A.Choname and S.D. AbouHussein.(2011).Foliar application of amino acids and micronutrients enhance performance of green bean crop under newly reclaimed land conditions .Austr.Jof Agric.Res.,5(6):459-469.

Abdel-Aziz, M.A. and M.S. Gaffer (2012).Effect of some treatments on enhqancing fruit set, yield and its quality of tomato (Lycopersicon esculentum, MILL) plants grown under high temperatures condition. Egypt .J. of Appl. Sci., 27(12 B):722749.

Abou El-Yazied, A.,A.M. El-Gizawy, M.I. Ragab and E.S. Hamed, (2012). "Effect of seaweed extract and compost treatments on growth, yield and quality of snap bean", J. of Amer. Sci., 8(6): $1-20$.

Abou El -Yazied,A. and M.A.Mady (2012). Effect of boron and yeast extract foliar application on growth, pod setting and both green and dry seed yield of broad bean (Vicia faba L.).J . of Appl.Sci.Res., 8(2):1240-1251.

Abubaker,S.(2008).Effect of plant density on flowering date ,yield and quality attribute of bush beans (Phaseolus vulgaris L.) under center

pivot irrigation system . Am. J. Agric. And Biol. Sci .,3(4):666-668.

Amer,S.S.A(2004) Growth, green pod yield and seeds yield of common bean (Phaseolus vulgaris L.) as affected by active dry yeast, salicylic acid and then interaction. J, Agric. Mansoura Univ., 29 (3) :1407-1422.

Ali,T.G.A.(2010). Physiological studies on growth,seeds yield and its quality of common bean.Ph.D.Thesis.Fac.of Agric., Benha Univ.

Arisha,H.M.and A.Bardisi (1999).Effect of nitrogen fertilization and plant spacing on growth ,yield and pod quality of common bean under sandy soil conditions Zagazig. J.Agric.Res.,26(2)407-419.
Barnett, J.A., R.W. Payne and D. Yarrow, (1990). "Yeasts, characteristics and identification. Cambridge Univ. Press. Published by the press syndicate of the Univ. of Cambridge. Camb. CB2 IBR, 40 West $20^{\text {th }}$ St., pp.999.

Bevilacqua,A.,M.R.Corob,M.Mastromatteo and M. Sinigaglia( 2008 ) Combind effect of $\mathrm{pH}$, yeast extract, carbohydrates and di -ammonium hydrogen citrate on the biomass production and acidifying ability of a probiotic lactobacillus plantarum strain, isolated from table olives, in a batch system. World J.Microbiol Biotechnol., 24: 1721-1729.

Blunden, G., (1991). Agricultural uses of seaweeds and seaweed extracts. In Guiry MD, Blunden G (eds) Seaweed resources in Europe. Uses and potential. Wiley, Chichester, pp: 65-81.

Bremner, J. M. and C. S. Mulvaney, (1982). Total nitrogen. In: Pag, A. L., R.H. Miller and D. R. Keeny (Eds).Methods of soil analysis. Part2, Amer.Soc .Agron.Madison, W.I.USA, 595-624.

Crouch, I.J. and J. Van Staden, (1994).Commercial seaweed products as biostimulants in horticulture", J. of Home and Consumer Horticulture, 1: 1976.

Darweesh,Fayza.M.A.,(2012). Cowpea (Vigna unguiculata L.) productivity as affected by combination effect between sowing dates and plant population.J.Plant

Production,Mansoura Univ.,3(11):2711-2722.

Einhelling,F.A.,(1986).Mechanisms and modes of action of allelochemicals. In :The science of allelopathy (Eds:A.R.Putnam and C.S.Tang). J.Willey and Sons.New York.pp.317-325.

El Naim A, M.and Jabereldar,A.A.(2010).Effect of plant density and cultivar on growth and yield of cow pea (Vigna unguiculata L Walp). Australian J.of Basic and Applied Sciences,4(8):3148-3153.

El-Awadi,M.E.,A.M. El-Bassiony , Z.F.Fawzy and M.A.El-Nemr.(2011). Response of snap bean (Phaseolus vulgaris L) plants to nitrogen fertilizer and foliar application with methionine and tryptophan .Nature and Sci.,9(5):87-94.

El-Desouky, S.A., F.H. Ismaeil, A.L. Wanas, E-S. L. Fathy and M.M. AbdEl-All, (2011). " Effect of yeast extract, amino acids and citric acid on physioanatomical aspects and productivity of tomato plants grown in late summer season", Minufiya J. Agric. Res., 36(4): 859-884.

El-Sheekh, M.M. and A.E.F. El-Saied,( 1999). "Effect of seaweed extracts on seed germination, seedling growth and some metabolic processes of faba beans (Vicia faba L.)", Phykos, (38): 55-64.

El-Tohamy, W.A. and N.H.M. El-Greadly,( 2007). "Physiological responses, growth, yield and quality of snap beans in response to foliar 
application of yeast, vitamin $\mathrm{E}$ and zinc under sandy soil conditions", Australian Journal of Basic and Applied Sciences, (3): 294-299.

FAO/TTC, (2001). World markets for organic fruits and vegetables: opportunities for developing countries in the production and export of organic horticultural products, TC/D/Y1669E/9.01/6730).

Fathy, E-S.L. and S. Farid,( 1996). “ The possibility of using vitamin B and yeast to delay senescence and improve growth and yield of common beans (Phaseolus vulgaris L.) ", J. Agric. Sci. Mansoura Univ., (4):1415-1423.

Fornes, F., M. Sánchez-Perales and J.L. Guadiola, (2002). " Effect of a seaweed extract on the productivity of 'de Nules' Clementine mandarin and navelina orange", Botanica Marina, (45): 486-489.

Gaafar,M.S.(2014).Studies on using safety compounds and the application methods on growth and yield of snap bean . Egypt J. of Appl.Sci., 29(2):54-81.

Goss, J. A. (1973). Amino acid synthesis and metabolism. In: New York. Physiology of Plant and their Cells. Pergamon Press, Inc., New York. 68-75.

IFAOM/SOEL,( 2000). “ World organic agriculture report”. Jackson, M.L., 1967. “ Soil chemical analysis”, prentic hallpvt. Itd. India, pp: 398.

Jackson,M.L.,(1970). Soil chemical Analysis. Prentic Hall, Englewood Ceiffs,N.J.

Kamal,A.M.and M.A.Abd Al-Gaid.(2008).Effect of foliar application with some antioxidants on growth and yield of pea (Pisum sativum L.) under early planting conditions. J.Agric. Sci. Mansoura Univ., 33(10):7413-7420.

Kazemi E .,R. Naseri, Z.Karimi and T.Emami(2012).Variability of grain yield and yield components of white bean (Phaseolus vulgaris $L$.)cultivars as affected by different plant density in Western iran. American Eurasian j. Agreic. \&Environ.Sci.,12(1):17-22.

Khan, W., U.P. Rayirath, S. Subramanian, M.N. Jithesh, P. Rayorath, D.M. Hodges, A.T. Critchley, J.S. Craigie, J. Norrie, B. Prithivira, (2009). " Seaweed extracts as biostimulants of plant growth and development", J. Plant Growth Regul., 28: 386-399.

Kumar,N.A.,B.Vanlalzarzova,S.Sridhar andM. Baluswami.(2012).Effect of liquied seaweed fertilizer of Sargassum wiahtii grev. On the growth and biochemical content of green gram(Vigna radiate (L.) R.wilczek.)Sci. and Techno. 4(4):4045.
Kraig, E. and J.E. Haber, 1980. " Messenger ribonucleic acid and protein metabolism during sporulation of Saccharomyces cerevisiae", J. Bacteriol., 144: 1098-1112.

Liu Xini,Li Yun and Zhang ShuQiu (2000).Effect of salicylic acid on growth and content of IAA and IPA of broad bean seedling. Plant physiology communications .36(6):512-514.

Mandour,M.S.,S.El-Sherbiny,N.B.Botrosand S.H.El-Nagar,(1986).Effect of nitrogen application upon growth, oil and nutrient content of citronella grass. Bull.Egypt,Soc.Physiol.Sci.145(3):6.

Marschner, H., 1995. " Mineral nutrition of higher plants", $2^{\text {nd }}$ ed. London, UK: Academic Press.

Mohamed,G.O.(2008).Effect of sowing date and plant density on growth and productivity of two faba bean (Vicia faba L.) cultivars.J.Agric.Sci., Mansoura Univ.,33(5):3167-3179.

Moniruzaman,M.,G.M.A.Halim and Z.A.Firoz.(2009).Performances of French bean as influenced by plant density and nitrogen .application.Bangladesh J. Agric Res.34(1):105111.

Nour, K.A.M.,G.S.A.Eisa (2009). Influence of some biofertilizers and foliar application with amino green and yeast on some botanical characters of snap bean under sandy soil condition. Zagzzig J. Agric. Res., 36 (5):987-1018.

Olsen, S. R. and L.E.Sommers, (1982) .Phosphorus. In: Page, A. L.; R. H. Miller and D. R. Keeney (Eds). Methods of soil analysis. Part 2 Amer. Soc. Agron. Madison, W. I. USA, 403-430.

Piper,G.S.(1947). Soil and Plant Analysis.Interscience Publishers,Inc.NY, 368P.

Pratelli, R. and G. Pilot, 2007. "Altered amino acid metabolism in glutamine dumper1 plants", Plant Signal Behav., 2(3): 182-184.

Sanaa,A.M.Z.;S.I.Ibrahim and H.A.M.S.EIdeen(2001). The effect of naphthalene acetic acid (NAA), salicylic acid on growth, fruit setting,yield and some correlated components in dry bean .Annals of Agric.Sci.Cairo, 46(2):451463.

Shady, M.A., 1978. " The yeasts", Adv. Cour. For Post Grad. St. In Microbiol, : Agric. Bot. Dept., Fac. of Agric., Mansoura Univ.146-247.

Snedecor,G.A. and W.G. Cochran (1980).Statistical Methods, 7th Ed.,The IowaState Univ., press, Ames.,Iowa,U.S.A.

Stewart, E. Allen (1989). Chmemical analysis of ecological materials.Black well Scientific publications. Oxford London Edin-burgh,368p.

Stitt, M., C. Müller, P. Matt, Y. Gibon, P. Carillo, R. Morcuende, W.R. Scheible and A. Krapp, 
2002. "Steps towards an integrated view of nitrogen metabolism”, J. Exp. Bot., 53(370): 959970.

Tartoura, E.A.A.(2001). Response of pea plants to yeast extract and two source of No. fertilizers. J. agric - sci. Mansoura Univ., 26 (12) .7887-7901. "General Viticulture", Univ. Cali. Press, USA.

Wallace,D.H.and H.M.Munger, (1965).Studies of the physiological basis for yield differences.1.growth and analysis of six dry bean varieties.Crop Sci.,5:343-348.
Winkler, A.J., J.A. Cook, W.M. Kliewer and L.A. Lider, 1962. "General Viticulture", Univ. Cali. Press, USA.

Zodape,S.T.,S.Mukhopadhyay,K.Eswaran,M.P.Red dy and J.Chikara (2010).Enhanced yield and nutritional quality in green gram (Phaseolus radiate $L$ ) treated with seaweed (Kappaphycus alvarezii) extract. J.of Scientific\&Industrial Res., 96:468-471. 


\title{
تأثثير الكثافة النباتية ويعض المركبات الآننة على نمو وإنتاجية الفاصوليا الخضراء
}

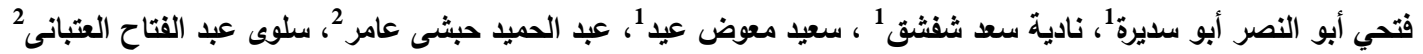 \\ 1- 1 قسم البساتين - كلية زراعة - جامعة بنها - مصر

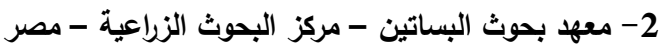

أجريت تجربتان حقلينان خلال الموسم الخريفى لعامى 2012/2011 فى محطة التجارب بقها محافظة القليوبية لدراسة تأثير استخدام أربع كثافات زراعية (5سم-7.5 سم على على ريثة واحدة و 10سم -15سم على ريشتى الزراعة) و خمس مواد أمنة وهى امينومور ( احماض امينية) -أوليجو

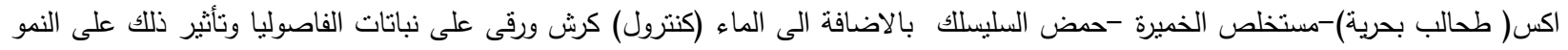

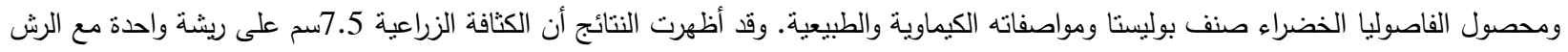

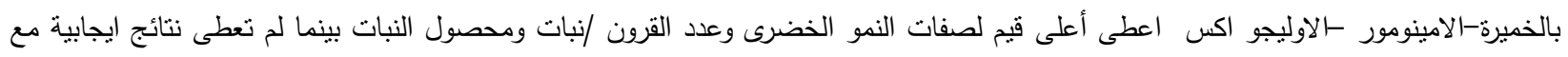
طول النبات -قطر الساق - المحصول الكلى للنبات ـ أعطت الكثافة النباتية 5سم على ريثة واحدة اعلى محصول مع الرش بالامينو مور في المئى الموسم

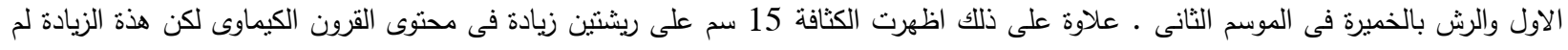

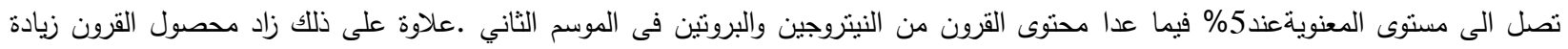

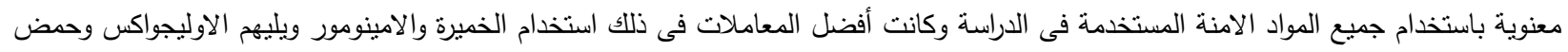

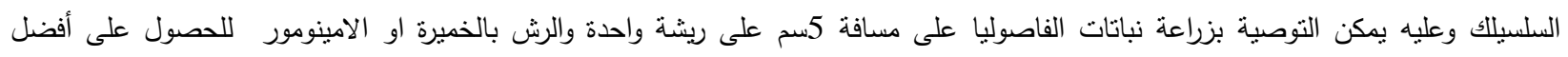
محصول من قرون الفاصوليا الخضراء. 